\title{
Kimozero, Karelia; a diamondiferous Palaeoproterozoic metamorphosed volcaniclastic kimberlite
}

\author{
Vladimir V. Ushkov ${ }^{1}$, Victor N. Ustinov ${ }^{2}$, Chris B. Smith ${ }^{3}$, Galina P. Bulanova ${ }^{4}$, Ludmilla I. \\ Lukyanova ${ }^{2}$, Daphne Wiggers de Vries ${ }^{5}$, D.Graham Pearson ${ }^{6}$. \\ ${ }^{I}$ Rio Tinto Exploration Pty. Ltd., Petrozavodsk, Russia., \\ ${ }^{2}$ ALROSA Co. Ltd., St. Petersburg, Russia \\ ${ }^{3}$ Rio Tinto Mining and Exploration Pty. Ltd., London, U.K., \\ ${ }^{4}$ University of Bristol, U.K., \\ ${ }^{5}$ Vrije Universiteit, Amsterdam, The Netherlands, \\ ${ }^{6}$ University of Durham, U.K.
}

\section{Geological setting}

Kimozero metakimberlite is located in Karelia, northwest Russia, $80 \mathrm{~km}$ north of Petrozavodsk, and is emplaced within a supercrustal Palaeoproterozoic intracratonic basin within the broader Archean Karelian Craton (Fig. 1).

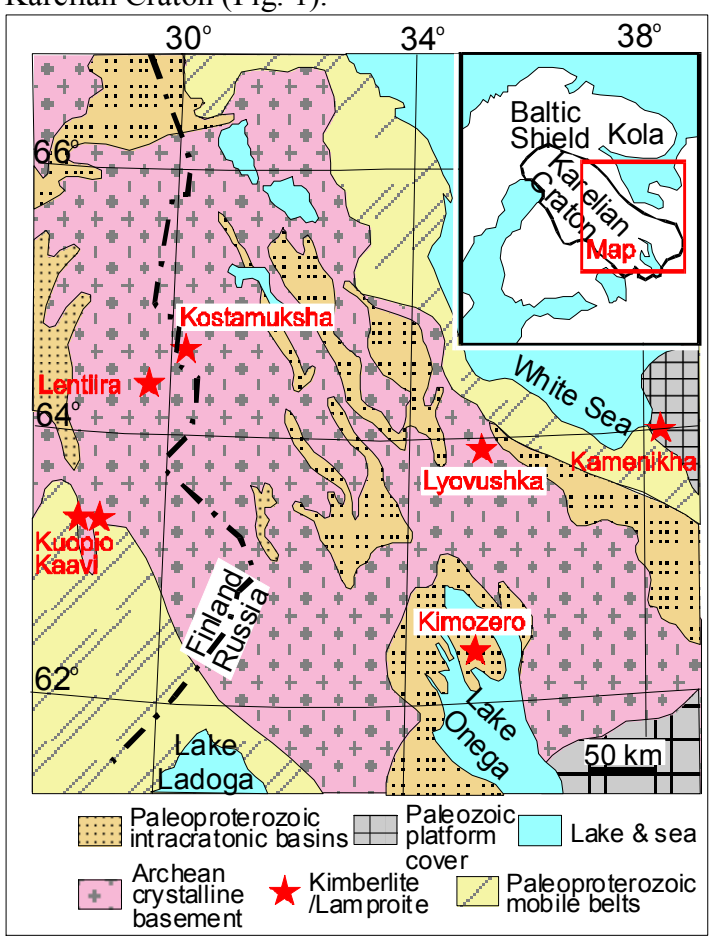

Fig. 1. Location of Kimozero and neighbouring kimberlites.

Kimozero metakimberlite has been dated at $1764 \pm 125$ Ma by the Sm-Nd method, this representing the age of metamorphism; hence the kimberlite may be older.

Country rocks consist of gently dipping metasedimentary schist and shungite, cut by tabular sill-like intrusive metadolerite, all folded into a shallow anticline. The anticlinal core is occupied by the metakimberlite which appears conformable within the country rock sequence, although slickensided outcrop suggests contacts with dolerite may be faulted. As the result of metamorphism the kimberlite has a superficial appearance of a metapyroxenite, sometimes micaceous, and often secondarily carbonated or impregnated with shungite or magnetite.

\section{Kimberlite geology}

The saucer-shaped Kimozero metakimberlite is $2 \mathrm{~km}$ long $\mathrm{x} 0.8 \mathrm{~km}$ wide ( $135 \mathrm{ha}$ ) but only $20-50 \mathrm{~m}$ deep (Fig. 2).

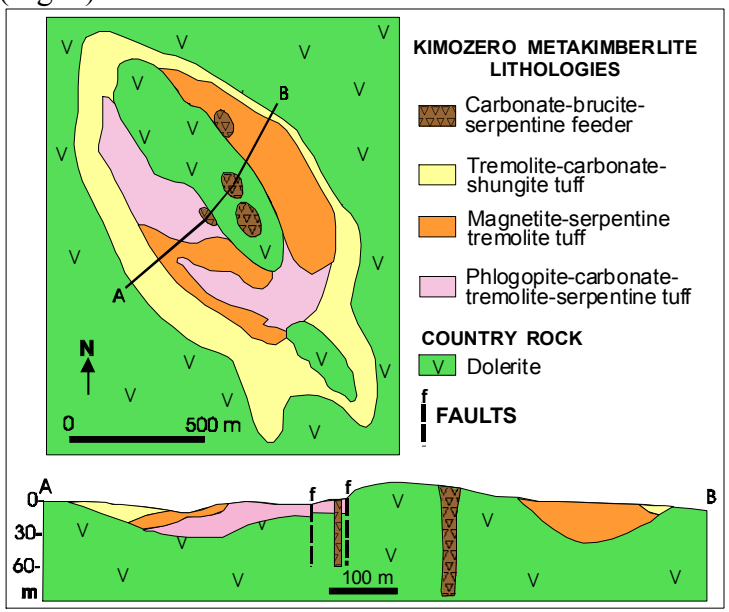

Fig. 2. Geological map and cross section of Kimozero metakimberlite.

The metakimberlite is composed predominately of subhorizontal lapilli-ash tuffs of two main types:

(i) massive unbedded tuffs showing weak clast imbrication suggestive of debris flow generation (Fig. 3 ), and

(ii) finely laminated, cross-bedded tuffs of apparent reworked, water-washed nature (Fig. 4).

Locally these tuffs are cut by five vertical bodies of coarser kimberlite tuffs forming narrow, steep-sided 
pipe-like structures interpreted as feeders, the largest of which is $100 \mathrm{~m}$ in diameter.

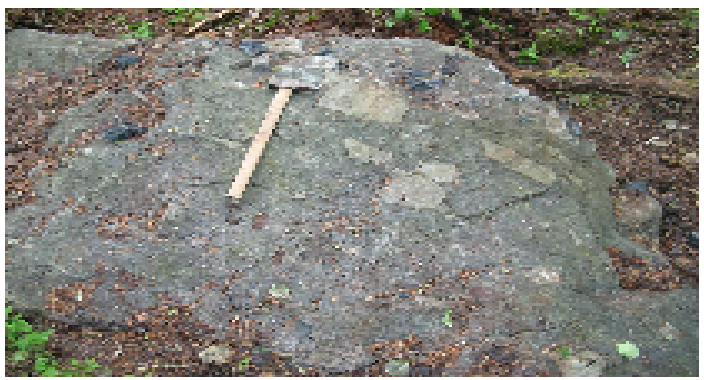

Fig. 3 Massive unbedded tuffs showing weak clast imbrication

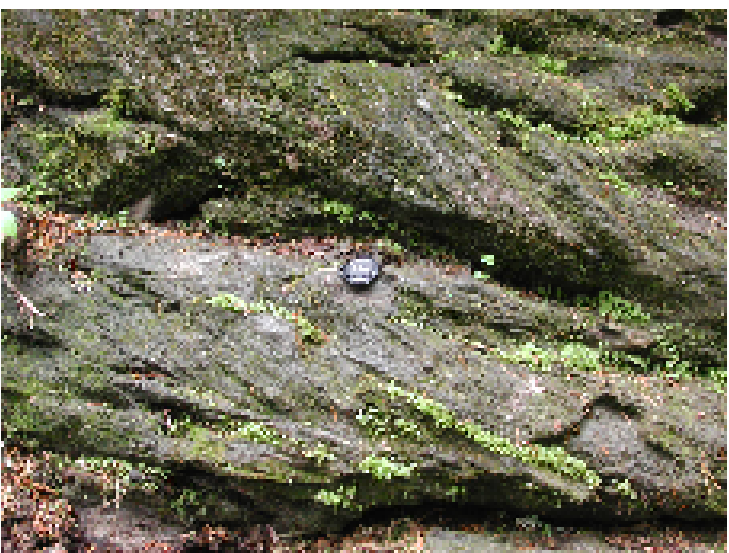

Fig. 4. finely laminated, cross-bedded tuffs.

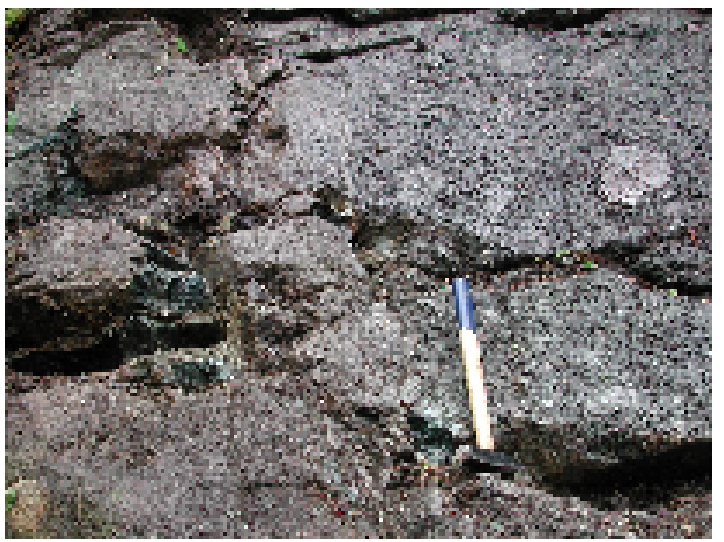

Fig. 5. Rare vertical hypabyssal kimberlite dykes (left half of photo above) also cut the tuffs.

\section{Petrography and mineralogy}

Primary minerals of Kimozero kimberlite are olivines pseudomorphed by serpentine and mica replaced by chlorite set in a matrix of secondary serpentine (antigorite), chlorite, carbonate, and ore minerals. Rare groundmass lath-like pseudomorphs have shapes suggestive of former melilite, a mineral characteristic of ultramafic lamprophyres (melnoite) but also found in some kimberlites (e.g. Finsch, Udachnaya).

The overall texture is porphyritic, due to the presence of large olivine macrocrysts and phlogopite, and fragmental with common kimberlite autoliths (Fig. 6). Large rounded and sub-rounded grains of olivine (up to
60-70 Vol. \%) reach 5-6 $\mathrm{mm}$ in length. Small oblong crystals of second generation $(<1 \mathrm{~mm})$ former olivine frequently preserve euhedral shape.

Amphibolitisation (tremolite, actinolite) is widespread with intensive development near the contacts with dolerite; carbonatisation is also widespread. The upper part of the main deposit is composed of carbonaceous kimberlite with the addition of shungite as fragments, intergranular impregnation, and injections into cracks and weakened zones. These superimposed processes frequently completely disguise the primary appearance of the kimberlite.

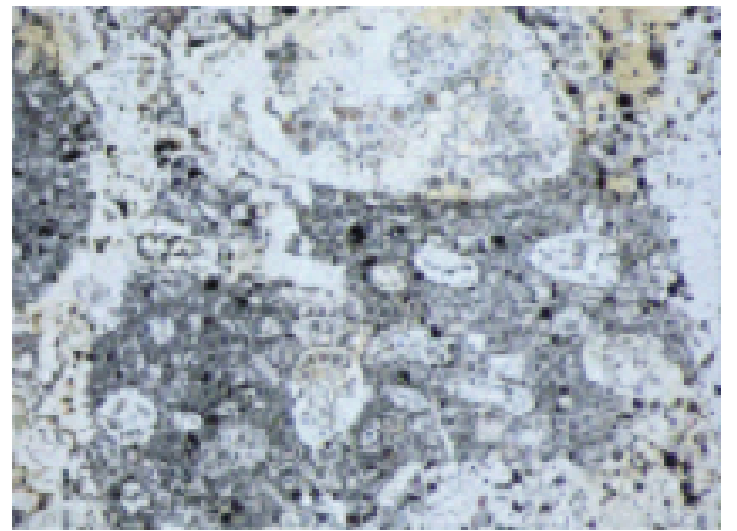

Fig. 6 Autolithic kimberlite with pseudomorphed olivines.

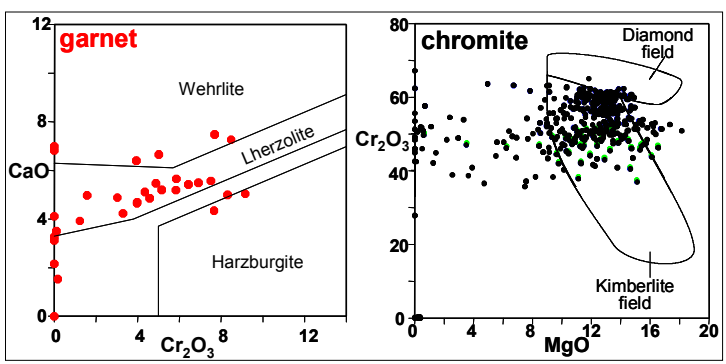

Fig. 7. $\mathrm{Cr} 2 \mathrm{O} 3-\mathrm{CaO}$ plot of pyrope and $\mathrm{MgO}-\mathrm{Cr} 2 \mathrm{O} 3$ plot of chromite from Kimozero concentrates.

The accessory kimberlite indicator mineral suite at Kimozero includes high $\mathrm{Cr}$ magnesiochromite, $\mathrm{Cr}$ pyrope (including subcalcic "G10" garnets) (Fig. 7), chrome diopside, and diamond, suggesting a conventional origin in lithospheric mantle.

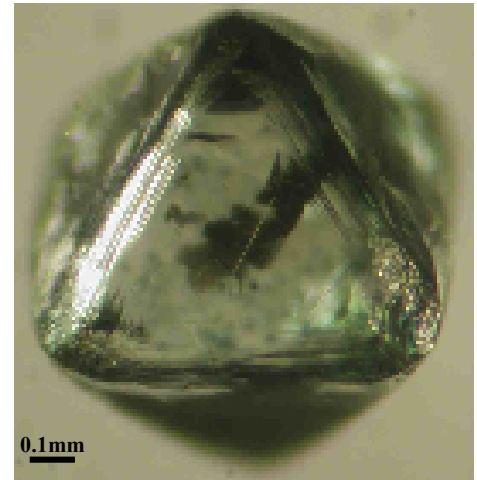

Fig. 8. Green, radiation-damaged octahedral diamond from Kimozero kimberlite. 
Kimozero diamonds are mainly planar octahedra with minor macles and aggregates, intensely green in colour due to radiation damage (Fig. 8). FTIR studies on several stones showed them to be plastically-deformed, $\mathrm{N}$-free type II.

They contain inclusions of Mg-rich orthopyroxene and pentlandite suggestive of peridotitic lithospheric mantle derivation. Preliminary Os data for sulphide inclusions give an unradiogenic ${ }^{187} \mathrm{Os} /{ }^{188} \mathrm{Os}$ ratio of 0.109 indicating a late Archean mantle source or older. This is consistent with the late Archean ages derived from peridotite xenoliths from the Kuopio-Kaavi kimberlites near the SW margin of the Karelian craton (Peltonen and Brügmann, 2006). Further data may constrain whether the Kimozero diamonds are indeed Archean or whether they are related to major tectonic events identified in the crust between 1.9 and $2.0 \mathrm{Ga}$ that appear to influence the Kuopio-Kaavi peridotite xenolith geochemistry (Peltonen and Brügmann, 2006).

\section{Geochemistry}

High Clement contamination indices reflect metamorphism and secondary alteration, with amphibolitisation and introduction of magnetite, shungite and carbonate. Nevertheless, high $\mathrm{MgO}$ and low concentrations of $\mathrm{SiO} 2, \mathrm{Al} 2 \mathrm{O} 3$ and contents and patterns of many lithophile elements and LREE enrichment are close to those of typical kimberlite.

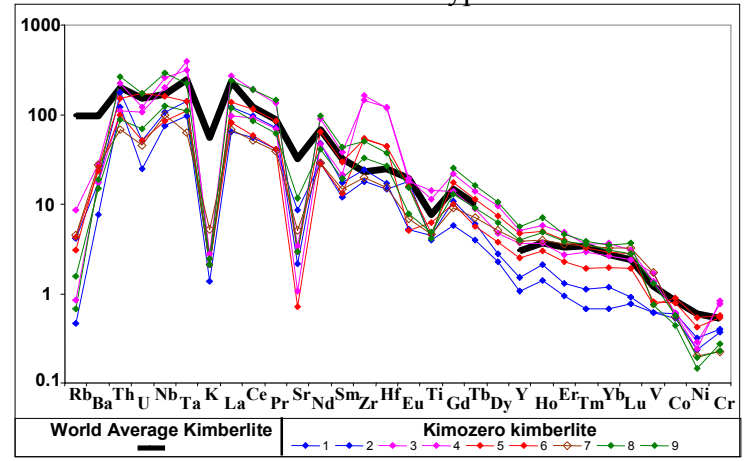

Fig. 9. Composition of Kimozero kimberlite and world average kimberlite normalised against primitive mantle.

\section{Comparison with other metakimberlites}

The structures and lithologies at Kimozero recall those of the diamondiferous Archean Wawa (Canada) lapilli tuffs and breccias and 2.1 Ga Dachine (Guiana) diamondiferous metamorphosed ultramafic tuffs conformably intercalated within greenstone sequences, inviting comparisons with these bodies. Chromite dominates the indicator mineral assemblage at each locality. Wawa diamonds by inclusion mineral species are harzburgitic and eclogitic (De Stefano et al., 2006, Stachel et al., 2006), with $\delta^{13} \mathrm{C}=-3.5$ to $-5.3 \%$ and $\mathrm{N}$ type IaA-IaB. Dachine diamonds are mainly octahedral monocrystals with eclogitic inclusions, dominantly low-Ni sulphides with minor omphacite (Bulanova, unpublished); $\mathrm{C}$ isotopes range from $\delta^{13} \mathrm{C}=$ 2 to $-22 \%$, supporting an eclogitic origin and the stones are predominately type II (Magee et al., 1999).
Wawa rock chemistry matches that of calc-alkaline lamprophyres (Lefebvre et al., 2003; Wyman et al., 2006) and Dachine chemistry resembles that of komatiite with no LREE enrichment (Bailey, 1999; Capdevila et al., 1999).

\section{Conclusions}

The petrography, mineralogy and geochemistry of Kimozero imply the volcanics are metamorphosed kimberlite. The metamorphosed diamond-bearing volcanics at Dachine and Wawa also carry lithospheric mantle-derived diamond, but the transporting magmas differ, only Kimozero having kimberlite chemical characteristics.

\section{References}

Bailey, L.M., 1999. An unusual diamond-bearing talc schist from the Dachine Area of French Guiana. M.Sc. Thesis, Queen's University, Kingston, Ontario, Canada, $159 \mathrm{p}$.

Capdevila R., Arndt N., Letendre J., Sauvage J.-F., 1999. Diamonds in volcaniclastic komatiite from French Guiana. Nature, v. 399, no. 6735, p. 456-458.

De Stefano, A., Lefebvre, N., and Kopylova, M., 2006. Enigmatic diamonds in Archean calc-alkaline lamprophyres of Wawa, southern Ontario, Canada Contributions to Mineralogy and Petrology, 151: $158-173$

Lefebvre, N., Kopylova, M., Kivi, K., and Barnett, R., 2003. Diamondiferous volcaniclastic debris flows of Wawa, Ontario, Canada, Long Abstract, 8th International Kimberlite Conference.

Magee, C.W., Williams, I.S., and Taylor, W.R., 1999. SHRIMP measurement of carbon isotopes in diamond. ANU Research School of Earth Sciences, Annual Rept., pp. 84-85.

Peltonen, P, and Brügmann, G., 2006. Origin of layered continental mantle (Karelian craton, Finland): Geochemical and Re-Os isotope constraints. Lithos 89 (2006) 405-423.

Stachel, T., Banas, A., Muehlenbachs, K., Kurszlaukis, S., and Walker, E.C., 2006. Archean diamonds from Wawa (Canada): samples from deep cratonic roots predating cratonization of the Superior Province. Contributions to Mineralogy and Petrology, 151: $737-750$

Ushkov, V.V., 2001. Kimozero occurrence of diamondiferous kimberlites in Onezhski Structure. Geology and Ore Deposits of Karelia. 2001, № 3, c. 94-98 (in Russian).

Wyman D.A., Ayer J.A., Conceição R.V., Sage R.P., 2006. Mantle processes in an Archean orogen: evidence from $2.67 \mathrm{Ga}$ diamond-bearing lamprophyres and xenoliths. Lithos, 2006, v. 89, no. 3/4, p. 300-328.

Zagayny, A.K., Ustinov, V.N., Zhuravlev, V.A., 2005. Structural tectonic factors of distribution of occurrences of kimberlite and lamproite magmatism in the northwest of the Eastern European Platform. Geology of Diamonds - Present and Future. Voronezh, Voronezhsky University, pp. 79-86 (in Russian 